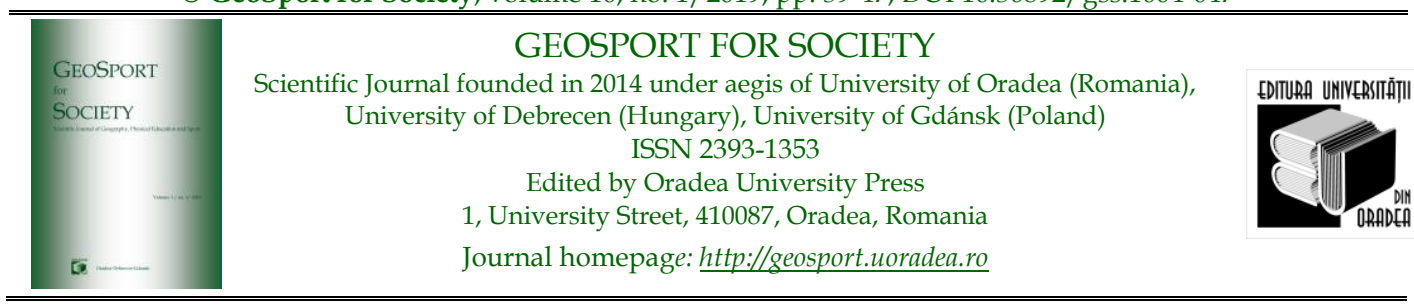

\title{
Motivating employees in sports organizations, an important factor in managerial policy
}

\author{
Paul Florian DRAGOŞ ${ }^{*}$, Grigore Vasile HERMAN², Mariana SZABO-ALEXI ${ }^{3}$, \\ Paul SZABO-ALEXI ${ }^{4}$, Varodi Mihaela OLĂU ${ }^{5}$, Sorin BUHAȘ 6
}

1. University of Oradea, Department of Physical Education, Sport and Physical Therapy, 1 University St., 410087 Oradea, Romania, e-mail: dpaul@uoradea.ro

2. University of Oradea, Department of Geography, Tourism and Territorial Planning, 1 University St., 410087 Oradea, Romania, e-mail: grigoreherman@yahoo.com

3. University of Oradea, Department of Physical Education, Sport and Physical Therapy, 1 University St., 410087 Oradea, Romania, e-mail:mariszabo@yahoo.com

4. University of Oradea, Department of Physical Education, Sport and Physical Therapy, 1 University St., 410087 Oradea, Romania, e-mail: pszabo@uoradea.ro

5. Ph.D. candidate, University of Oradea, Department of Geography, Tourism and Territorial Planning, 1 University St., 410087 Oradea, Romania, e-mail: oradeanu_miha@yahoo.com

6. University of Oradea, Department of Physical Education, Sport and Physical Therapy, 1 University St., 410087 Oradea, Romania, e-mail: sorin.buhas@gmail.com

* Corresponding author

Citation: Dragoș, F. P., Herman, G. V., Szabo-Alexi, M., Szabo-Alexi, P., Olău, V. M., Buhaș, S. (2019). Motivating employees in sports organizations, an important factor in managerial policy. Geosport for Society, 10(1), 39-47. https://doi.org/10.30892/gss.1004-047

Article history: Received: 05.004.2019; Revised: 20.05.2019; Accepted: 28.06.2019, Available online: 04.07.2019

\begin{abstract}
The present study aims at highlighting methods and means that can be used to increase the efficiency of employees in sports organizations. It started from the hypothesis that work performance in sports organizations depends on how managers manage to identify and meet the needs or expectations of executives. In this respect, using the method of the questionnaire, 178 persons (51 managers and 127 employees) were consulted on the institutional actions (taking place within the sports organization of which they belong) and regarding their expectations and needs.
\end{abstract}

Keywords: managers, employees, motivation, attitudes, actions, expectations, needs 


\section{Introduction}

At similar global motivational intensities, work behavior will be differentiated according to the share of intrinsic factors in relation to extrinsic factors in determining the overall motivational index (Mamali, 1981).

The motivation and the satisfaction of a person's work are not only conditioned by the productive work carried out in a given job, but also by the activity and extraprofessional factors throughout the everyday life of the person. Motivation and work satisfaction should be understood as components of the entire motivational structure and the overall state of personality satisfaction.

Increasing the degree of cohesion within an organization has the effect of positively influencing the motivation of its members. This increase can be made simpler by all employees participating in different joint actions: company-sponsored parties, meals, etc.

Organizations need to discover natural ways of communicating with employees so that they know their needs, abilities, values, professional aspirations, career development goals. And leaders need to learn to pass on to the employees the messages and goals of the organization so they can be understood and assumed. They have to give decision makers and active roles to their employees to stimulate them and use their abilities to make them more responsible and to increase their self-esteem.

The importance of this study is based on the need to motivate and increase the interest of the employees of sports organizations so that they can be considered part of the decision area (Huffman et al., 1991; Johns, 1996). Increasing the involvement in the decision-making process, but also the employee's feeling that his work contributes to the success of the sports organization, represents an important objective of institutional management, but also a way to success (Zlate, 2000). In this context, management finds a way to motivate employees to increase the level of satisfaction (Ziglar and Savage, 1998; Wiley, 1997; Beck, 2004; Gorman, 2004; Sinclair et al., 2006; Dragos, 2014b). It can be highlighted in various ways: remuneration, certain material benefits, appreciation, better working conditions, etc. (Marcu \& Buhas, 2014; Dragos, 2014a; Buhas, 2015a).

A series of studies highlighted the importance of employee motivation, so that the degree of satisfaction is directed towards ensuring an emotional balance, a wellbeing, the enjoyment of the job attendance, so as to increase the productivity of work and thus achieve the performance parameters Dragos, 2015; Buhas, 2015b; Buhas $2015 \mathrm{c}$ ). The human resource has evolved lately on the organizational priority scale. Thus, there has been a translation from the simple notion of capital to that of psychological capital that is necessary to be motivated to manifest itself positively (Deci \& Ryan, 2008, McAdam, 2008).

\section{Research Methodology}

This study is based on the results of the study of the literature and the use of the sociological questionnaire survey (Babbie, 2010; Bar et al., 2016; Herman et al., 2016; Ilieș et al., 2015; Tătar, 2013, 2018; Wendt et al., 2019). From a structural point of view, the applied questionnaire covered two major aspects: institutional actions 
(taking place within the sports organization of the respondents), respectively, their expectations and needs. Within the framework of the institutional actions, four major issues of concern were addressed: organizing meetings to celebrate the success of some employees; organizing awarding actions for quantifiable results, special initiatives, perseverance, etc.; celebrating a date as the day of the company in which all employees are involved and celebrating those who reach the retirement age. Information on the expectations and needs of the respondents came out through the expression of availability (to work hard, to work in a team, to execute orders without engagement, to enter into conflict, to take responsibility) and needs (the need for socialization and recognition of merits). The geo-socio-demographic data, like the city of origin, the size of the organization they belong to, their position in the organization, the level of education, age and gender were also captured in the questionnaire. The questionnaires were applied directly to the subject.

Considering the representativeness of the sample group, this study was carried out on 200 people from 34 sports organizations in the country, including 60 managers, 140 employees in execution structures. Due to the reticence of some of the respondents and the mistakes raised in completing the questionnaires, the information from 178 questionnaires (51 questionnaires filled in by managers and 127 questionnaires filled in by employees) was used.

The sampling was mixed (random and directed) with regard to sports organizations of different sizes and different statutes; the investigated subjects were selected primarily because of the willingness to respond to the questionnaires.

The analysis of the respondent target group highlights the following defining characteristics:

The analysis of the respondent target group highlights the following defining characteristics:

- place (in case of managers 23\% are from Oradea, 21\% from Cluj Napoca, 20\% from Timisoara and Bistrita, $8 \%$ from Arad. In case of employees $26 \%$ are from from Oradea, from Bistrita 21\%, from Timisoara 20\%, Cluj Napoca 18\% and from Arad 15\%);

- the size of the organization $12 \%$ of respondents, both managers and employees work in small sports organizations, $27 \%$ of managers and $20 \%$ of employees belong to medium-sized sports organizations and $61 \%$ of managers and $68 \%$ of employees are from large sports organizations);

- the position within organisation (29\% of the managers were directors, $23 \%$ were vice-presidents, $12 \%$ were president, $12 \%$ deputy directors, also, $12 \%$ councilors, $6 \%$ finacial responsible and also, $6 \%$ other sector responsible. In the case of employees or executives, the functions they occupy are quite varied. Most of them there were coaches $(38 \%)$ or just trainer $(24 \%), 8 \%$ of them were competition organizers and $5 \%$ were heads of the departments and $4 \%$ were referents. There is another category of $8 \%$ occupied by other positions (drivers, etc.)

- the level of education (53\% of the managers have higher education (bachelor degree), $29 \%$ postgraduate studies and $18 \%$ with a doctoral degree. For the majority of employees (52\%) have higher education, $23 \%$ have postgraduate studies and only $27 \%$ are based only on high school degree); 
- age (managers aged 46-55 are 47\%, and those between 36-45 years and 5665 years are in relatively equal proportions, ie 24\% and 29\% respectively for the second $31 \%$ of employees are up to 35 years and between $46-55$ years, $22 \%$ are between 36 and 45 years and the rest $16 \%$ are over 56 years old);

- gender (88\% of managers and $80 \%$ of employees are men).

\section{Institutional Actions}

\section{Organizing meetings to celebrate the success of some employees}

Meetings initiated by management to celebrate the success of employees can be an important motivating factor as it reflects on the needs of merit recognition personnel. Those who understand the importance of recognizing employees' merits only gain. They know that recognition is not just a symbolic thing on their part, but a real motivation tool for employees. It is an enhanced form of communication: you confirm that it is on the right track and motivate it to repeat those actions.

In sportive organizations surveyed, $53 \%$ of respondents $(57 \%$ of managers and $52 \%$ of employees) declare that meetings are held in the sports organizations of which they are part to celebrate the success of employees (table 1).

Table 1. Centralized table with results from respondents

\begin{tabular}{|c|c|c|c|c|c|c|c|}
\hline \multirow{2}{*}{ No. } & \multirow{2}{*}{ Questions } & \multicolumn{2}{|c|}{ Manager } & \multicolumn{2}{|c|}{ Employee } & \multicolumn{2}{|c|}{ Total } \\
\hline & & No & Yes & No & Yes & No & Yes \\
\hline 1 & INSTITUTIONAL ACTIONS & & & & & & \\
\hline 1.1 & $\begin{array}{l}\text { Do you have meetings to celebrate the success } \\
\text { of employees in your sports organization? }\end{array}$ & $\begin{array}{c}22 \\
43 \% \\
\end{array}$ & $\begin{array}{c}29 \\
57 \% \\
\end{array}$ & $\begin{array}{c}61 \\
48 \% \\
\end{array}$ & $\begin{array}{c}66 \\
52 \% \\
\end{array}$ & $\begin{array}{c}83 \\
47 \% \\
\end{array}$ & $\begin{array}{r}95 \\
53 \% \\
\end{array}$ \\
\hline 1.2 & $\begin{array}{l}\text { In the sports organization where you are } \\
\text { active, awards are organized for quantifiable } \\
\text { results, special initiatives, perseverance, etc.? }\end{array}$ & $\begin{array}{c}6 \\
12 \%\end{array}$ & $\begin{array}{c}45 \\
88 \%\end{array}$ & $\begin{array}{c}76 \\
60 \%\end{array}$ & $\begin{array}{c}51 \\
40 \%\end{array}$ & $\begin{array}{c}82 \\
46 \%\end{array}$ & $\begin{array}{c}96 \\
54 \%\end{array}$ \\
\hline 1.3 & $\begin{array}{l}\text { In the sports organization where you activate, } \\
\text { is a date celebrated as the day of the company } \\
\text { in which all employees are involved? }\end{array}$ & $\begin{array}{c}18 \\
35 \%\end{array}$ & $\begin{array}{c}33 \\
65 \%\end{array}$ & $\begin{array}{c}60 \\
47 \%\end{array}$ & $\begin{array}{c}67 \\
53 \%\end{array}$ & $\begin{array}{c}78 \\
44 \%\end{array}$ & $\begin{array}{r}100 \\
56 \%\end{array}$ \\
\hline 1.4 & $\begin{array}{l}\text { In the sports organization where you are } \\
\text { activating, do you celebrate people who reach } \\
\text { retirement age? }\end{array}$ & $\begin{array}{c}21 \\
41 \%\end{array}$ & $\begin{array}{c}30 \\
59 \%\end{array}$ & $\begin{array}{c}69 \\
54 \%\end{array}$ & $\begin{array}{c}58 \\
46 \%\end{array}$ & $\begin{array}{c}90 \\
51 \%\end{array}$ & $\begin{array}{c}88 \\
49 \%\end{array}$ \\
\hline 2 & EXPECTATIONS AND EMPLOYEES 'NEEDS & & & & & & \\
\hline 2.1 & I like to work hard & $\begin{array}{c}36 \\
71 \% \\
\end{array}$ & $\begin{array}{c}15 \\
29 \%\end{array}$ & $\begin{array}{c}83 \\
65 \% \\
\end{array}$ & $\begin{array}{c}44 \\
35 \%\end{array}$ & $\begin{array}{l}119 \\
67 \% \\
\end{array}$ & $\begin{array}{c}59 \\
33 \% \\
\end{array}$ \\
\hline 2.2 & I like to have friends & $\begin{array}{c}24 \\
47 \% \\
\end{array}$ & $\begin{array}{c}27 \\
53 \%\end{array}$ & $\begin{array}{c}69 \\
54 \% \\
\end{array}$ & $\begin{array}{c}58 \\
46 \% \\
\end{array}$ & $\begin{array}{c}93 \\
52 \% \\
\end{array}$ & $\begin{array}{c}85 \\
48 \%\end{array}$ \\
\hline 2.3 & I like to take responsibility & $\begin{array}{c}18 \\
35 \% \\
\end{array}$ & $\begin{array}{c}33 \\
65 \% \\
\end{array}$ & $\begin{array}{c}83 \\
65 \% \\
\end{array}$ & $\begin{array}{c}44 \\
35 \% \\
\end{array}$ & $\begin{array}{c}101 \\
57 \% \\
\end{array}$ & $\begin{array}{c}77 \\
43 \% \\
\end{array}$ \\
\hline 2.4 & I like to work alone & $\begin{array}{c}33 \\
65 \% \\
\end{array}$ & $\begin{array}{c}18 \\
35 \% \\
\end{array}$ & $\begin{array}{c}88 \\
69 \% \\
\end{array}$ & $\begin{array}{c}39 \\
31 \% \\
\end{array}$ & $\begin{array}{l}121 \\
68 \% \\
\end{array}$ & $\begin{array}{c}57 \\
32 \% \\
\end{array}$ \\
\hline 2.5 & $\begin{array}{l}\text { I'm in conflict with those who do not do the } \\
\text { things I want }\end{array}$ & $\begin{array}{c}48 \\
94 \% \\
\end{array}$ & $\begin{array}{c}3 \\
6 \% \\
\end{array}$ & $\begin{array}{l}121 \\
95 \% \\
\end{array}$ & $\begin{array}{c}6 \\
5 \% \\
\end{array}$ & $\begin{array}{r}169 \\
95 \% \\
\end{array}$ & $\begin{array}{c}9 \\
5 \% \\
\end{array}$ \\
\hline 2.6 & I feel satisfied when my merits are recognized & $\begin{array}{c}27 \\
53 \%\end{array}$ & $\begin{array}{c}24 \\
47 \%\end{array}$ & $\begin{array}{l}116 \\
91 \%\end{array}$ & $\begin{array}{c}11 \\
9 \%\end{array}$ & $\begin{array}{c}143 \\
80 \%\end{array}$ & $\begin{array}{c}35 \\
20 \%\end{array}$ \\
\hline
\end{tabular}




\section{Organizing award actions for quantifiable results, special initiatives, etc.}

Positive feedback is a simple, handy and very effective way of motivation. A satisfied and motivated employee care about the work they are doing and does not do things just to be done, but does as much as possible. In this sense, the award is another very important motivating factor in the life of a sports organization. The opinion of the questioned managers emphasizes this idea, with $88 \%$ of them saying that this type of action is organized regularly in the organizations where they operate. This is not the case with the employees, with only $40 \%$ saying that the award is part of the motivation policy existing in the sports organizations under investigation (table1).

\section{Celebrate a date as the day of the company where all employees are involved}

Celebrating a date as the day of the company can be an optimal opportunity for both the organization and its employees to get to know each other better. In the sports organizations surveyed, managers say $65 \%$ of the total of those questioned have such actions, the employees being only 53\% in agreement with this variant (table 1).

\section{Celebration of people reaching the retirement age}

The attitude in an organization towards retired people shows the degree of appreciation the organization's leadership has in the first place towards the employees. Even more so, for retired people, it can be a recognition of merit and an appreciation of what they have done throughout their careers. It is important for an employee to see that his merits are recognized even if this recognition does not imply financial reward. This is because appreciation has a positive effect on employees: they trust themselves and are more motivated, which is essential in any organization. The dissatisfaction of the person who finds that his or her contribution has not been rewarded with due appreciation leads him to reconsider his attitude towards work and to start saving effort. In sport organizations included in the research, the actions for celebration of the persons reaching the retirement age take place, in terms of managers, in $59 \%$ of the cases. From the perspective of employees, only $46 \%$ of them consider that this type of activity is organized in the places where they operate (table 1 ).

\section{Expectations and Employees 'Needs}

The availability of managers and employees for work, the need for friends and group affiliation that can increase team cohesion, the ability of the individual to take responsibility, preferences for group or individual work, engagement in executing orders, need for appreciation and recognition of merits, s.a.m. are primary elements that must be known to managers to meet them. If we do not really know our employees and their needs, we cannot motivate them to work on true capacity.

Of all kinds of activities, work occupies the most important place in human life. The choice of the profession and the adaptation to its requirements presuppose the continuation of a personality development direction that allows the development of skills and aptitudes, the expression of values and attitudes, the assimilation of agreeable roles, the professional success being ultimately, a result of the interaction between the personality structure and the occupational environment. The personality 
and self-identity of the adult are closely related to his/her main activity-work. Developing personality as a continuous process depends on a number of factors that can be grouped into three categories: life cycles, the choices we make more or less by chance, and self modelation. These choices, including that of profession have an important role: a highly demanding position in terms of intellectual trait influence not only on the development of skills and abilities, but also on interests, motivation, aspirations, manifestations of the ego.

\section{Availability for intensive work}

The work-related opinion of surveyed people reveals that $29 \%$ of managers and $35 \%$ of employees are willing and willing to work hard. The remaining $71 \%$ managers and $65 \%$ employees do not like this effort (table 1).

\section{The need for socialization}

The concept of human relations occupies a privileged place in social psychology. From the very definition of this discipline it follows that its main concern is the interaction between the social actors, the relations between personalities in a social field (group, organization). The relationship or bond is the very way of expressing the human individual, placed in a context. Interaction develops, human intelligence, competencies are valued, influences are exercised, or human socialization is achieved. Relationship with others, whether parents, brothers, groups of friends, institutions, and organizations, employs each individual on a network of connections, inserts it, asks him, and stimulates him to develop his skills. We need another to confirm our identity or critically evaluate our attitudes and behaviors. By another we come to know ourselves better; another is our mirror image, an Alter-Ego. At the same time, another is a support for each of us: it influences our aspirations and enriches us through its knowledge and culture through its intellectual behaviors and attitudes; helps us overcome critical situations, imposes ideas through his authority or opposition to some of our inappropriate attitudes and gestures.

The need or the pleasure of having many friends for interviewees reveals that $53 \%$ of managers and $46 \%$ of employees would like or would like to have as many friends as $47 \%$ of managers and $54 \%$ of the employees did not express this need.

\section{Taking responsibility}

Some of the most effective ways to motivate employees are: to offer rewards, recognition, positive feedback, and last but not least to bring to the attention of others in the organization who were responsible for the activity worthy of praise and/or effort. Too often, employees are led through "mismanagement" where most feedback is corrective or punitive. If employees feel that their decisions are supported, and when they are guided to the right direction, they will be more positive, confident and ready to take responsibility for making decisions.

In sports organizations included in the research, assuming responsibility is characteristic of $65 \%$ of the interviewed executives and only $35 \%$ of the employees. The remaining 35\% managers and $65 \%$ employees prefer not to take on major responsibilities (table 1). 


\section{Availability for teamwork}

In theory, ideal teamwork is great: Teamwork involves the ability to work together to achieve a common vision. Ability to direct individual achievements to meet organizational goals. Fuel that allows normal people to achieve outstanding results (Katzenbach and Smith, 2015; Kouzes and Posner, 2006). In reality, relationships are not so complex and the competitive spirit is integrated: Most teams are not teams, but only collections of individual subordinate relationships. Each individual fighting with others for power, prestige and position (Yukl, 1998; Eisenhardt, 1989).

Each person has a result on work done individually and another in a team. He also prefers to be accountable and to control how they work, their decisions and their results. If team members have individual responsibilities, their work will be more effective. Lack of individual responsibilities will allow the guilty to be thrown over to the other team members.

The preference of individuals questioned about individual work reveals a rather low preference towards this form, only 35\% of managers and $31 \%$ of employees being in agreement with this possibility. Most of them, namely $65 \%$ of managers and $69 \%$ of employees, prefer teamwork.

\section{Availability to execute orders}

Participatory leadership is good when people already have experience and often come up with very good solutions. The decision is also taken by the manager but following consultation with the employees. The chance of a better final decision is much greater in this situation because the solution found by the manager can be "fined" in a positive sense by other solutions coming from experienced and not only people. The condition for achieving this style is that the manager is open to receiving solutions (Wagner and Harter, 2009). Participation increases the motivation of subordinates to contribute to goal setting and decision-making and can lead to easier decisions by subordinates. Also, the motivation of employees to carry out tasks would increase.

Analyzing employees' willingness to execute orders without engagement reveals that both managers and employees claim to be involved in executing orders, while only $6 \%$ of the first category and $5 \%$ of the second, respectively, execute the orders without is involved.

\section{Availability of conflict}

Workplace conflicts are based on interactions between employees at work, so we can speak of interpersonal conflicts. This conflict can arise between colleagues inside departments, between different departments or within the management team. Conflicts are based on negative behaviors. Emotional attitudes, manipulations of any kind, conflicts of interest, lack of tolerance, selfish behavior towards managers or employees' colleagues easily develop conflicts, generating feelings of frustration, rage, verbal violence. The stubbornness, the impressions of some people that they are right or wrong, the fact that employees do not always perform tasks as managers like, generates multiple conflicts at work with different intensities. 
In this research, the managers' opinions are different from those of the employees, which is somehow normal, because their position gives them the right to be upset or to conflict with those who do not do the things as they would like. The analysis of the answers received shows that $53 \%$ of the surveyed managers are in conflict with those who do not do the job as they wish, while among the employees only $9 \%$. In contrast, there are $47 \%$ managers and $91 \%$ employees (table 1 ).

\section{Recognition of merit}

Efficient managers understand the strength and importance of recognizing employee outcomes. They know that recognizing employees' merits is not only a good way to strengthen interpersonal relationships but a communication tool that strengthens the very foundation of the business: people and their relationship with the organization. A good manager is the one who leads the team to achieve the proposed results with as few resources as possible in the shortest possible time. A leader will make all people want to reach those goals, making them feel important and appreciated. The leader must find opportunities for an employee to be rewarded and recognized. A good leader must ensure that the environment in which his team works provides the prerequisites for each member to feel important and appreciated. Also, even managers feel the need for appreciation and recognition of merits by both subordinates and potential managers at higher levels.

Thus, the results of the analysis carried out that managers and especially employees, need to be appreciated when the results are recommended, $82 \%$ of surveyed managers and $91 \%$ of employees stating that they are satisfied when their merits are acknowledged (table 1 ).

\section{Conclusions}

The analysis of the data obtained from interviewees (51 managers, 127 employees) involved in the functional management of sports organizations from the North-West part of Romania (Timişoara, Arad, Cluj Napoca, Oradea and Bistriţa) highlighted several relevant aspects. Thus, in sports organizations, from the perspective of motivation at the workplace, the rewarding (and not necessarily material) rewarding action for the merits of the employees for the results obtained over time is of great importance, both the managers (57\%) and employees (52\%) express same opinions.

It is therefore necessary to organize meetings aimed at celebrating the retired persons, those who achieve great results through their work, but also to establish and maintain a favorable climate in the workplace.

Also, another important element in employee motivation confirmed by data analysis is communication, with management feedback being able to avoid conflicting situations and misunderstandings due to lack of information.

From the point of view of the study, there is also the fact that there are people who are more efficient and implicitly more motivated by teamwork, others who prefer to work alone and some who accept the situation as it is. The duty of managers is to identify the needs and aspirations of each and to find ways to involve them in the activities appropriate to each character type. 


\section{References}

Babbie, E. (2010). The Practice of Social Research, Polirom Publishing House Iași (in Romanian).

Bar, R., Tătar, C., F., \& Herman, G., V., (2016). Satisfaction Degree Rating of Tourist Services in Buziaș Spa, Timiș County, Romania. GeoJournal of Tourism and Geosites, 18(2), 212-223.

Beck, R. C. (2004). Motivation: Theories and Principles, NY: Prentice Hall.

Buhaș, S. D. (2015a). Sport management. From institutionalism to research. Geosport for Society, 2(1), 26-32.

Buhaș, S. D. (2015b). Strategii manageriale, cluburile de fotbal din liga 1 [Management strategies. Football clubs in League I], Eikon Publishing House, Cluj Napoca (in Romanian).

Buhaș, S. D. (2015c). Managementul organizațiilor sportive [The management of sports organizations], Eikon Publishing House, Cluj Napoca (in Romanian).

Deci, E., \& Ryan R. (2008). Self-Determination Theory: A Macrotheory of Human Motivation, Development and Health. Canadian Psychology, 49(3), 182-185.

Dragoș, P. (2014a). Financial Reward and its Effects on Managers and Employees in the Sport Organisations. Studia Universitatis Babeș-Bolyai, Educatio Artis Gimnastical, 59(4), 123-130.

Dragoș, P. (2015). Aspects regarding efficiency at work in certain Sport organisations. Geosport for Society, 2(1), 21-26.

Dragoș, P. F. (2014b). Study regarding the role of motivation in the sport performance activities. Baltic Journal of Health and Physical Activity, 6(1), 45-55.

Eisenhardt, K. M. (1989). Making fast strategic decisions in high-velocity environments. Academy of Management journal, 32(3), 543-576.

Gorman, Ph. (2004). Motivation and emotion. New York: Routledge, Taylor \& Frencis Group.

Herman, G. V., Grama, V., Buhaș, R., Ilieș, D. C., \& Stance, L. (2016). Research on the professional trajectory of the highschool and university students from the fields of geography and physical education. Analele Universitatii din Oradea, Seria Geografie, 26(1), 54-62.

Huffman, K., Vernoy, M., \& Vernoy, J. (1997). Psychology in action. New York: John Wiley and Son.

Ilieș, D. C., Buhaș, R., Ilieș, A., Morar, C., \& Herman, G. (2015). Nymphaea lotus var. Thermalis (Pârâul Peţea Nature Reserve), Brand Near Extinction of the Băile Felix-Băile 1 Mai (Romania) Spa Tourism System. GeoJournal of Tourism \& Geosites, 15(1), 107-117.

Johns, G. (1996). Comportament organizaţional, Editura Economică, Bucureşti.

Katzenbach, J. R., \& Smith, D. K. (2015). The wisdom of teams: Creating the high-performance organization. Harvard Business Review Press.

Kouzes, J. M., \& Posner, B. Z. (2006). The leadership challenge (Vol. 3). John Wiley \& Sons.

Mamali, C. (1981). Balanţa motivaţională şi coevoluţie, Editura Ştiinţifică şi Enciclopedică, Bucuresti.

Marcu, V., \& Buhaş, S. (2014). Sports Organizations - Management and Science. Procedia-Social and Behavioral Sciences, 117, 678-682.

McAdam, N. (2002). A brain styles model of change responsiveness and distributed leadership in 21st century network organisations. International Journal of Organisational Behaviour, 5(7), 213-241.

Sinclair, C., Dowson, M., \& McInerney, D. M. (2006). Motivations to teach: Psychometric perspectives across the first semester of teacher education. Teachers College Record, 108(6), 1132-1154.

Tătar, C. F., \& Herman, G. V. (2013). Identity Encounters, Host-Guest Interractions in the Land of Moţi. GeoJournal of Tourism and Geosites, 11(1): 66-74.

Tătar, C. F., Herman, G. V., \& Gozner, M. (2018). Tourist Guides' Contribution to Sustainability in Romania. GeoJournal of Tourism \& Geosites, 21(1): 282-287.

Wagner, R., \& Trif, R. N. (2009). Cele 12 elemente ale managementului performant. Allfa.

Wendt, J. A., Buhaș, R., \& Herman, G. V. (2019). Experience of the Baile-Felix tourist system (Romania) for the protection and promotion of the grey seal as a brend on the Hel Peninsular (Poland). Baltic Region, 11(1), 109-136.

Wiley, C. (1997). What motivates employees according to over 40 years of motivation surveys. International Journal of Manpower, 18(3), 263-280.

Yukl, G. A. (1998). Leadership in organizations. Pearson Education India.

Ziglar, Z., \& Savage, J. (1998). Motivatia. O cale spre performante deosebite, Business Tech International Press, Bucuresti.

Zlate, M. (2000). Introducere în psihologie, Iaşi: Polirom. 